\title{
PECULIARITIES OF INVENTORY MANAGEMENT STRATEGIES OF LITHUANIAN MANUFACTURING COMPANIES
}

\author{
Virgilija Vasilienè-Vasiliauskiené $\dot{ }^{1}$, Aidas Vasilis Vasiliauskas ${ }^{2}$, \\ Kristina Čižiūniene் $\dot{3}^{3}$, Greta Kaknevičiūtè ${ }^{4}$ \\ 1,3,4 Department of Logistics and Transport Management, \\ Vilnius Gediminas Technical University, Plytinès 27, Vilnius, Lithuania \\ ${ }^{2}$ General Jonas Žemaitis Military Academy of Lithuania, Šilo 5A, Vilnius, Lithuania

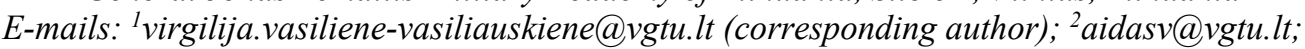 \\ ${ }^{3}$ kristina.ciziuniene@vgtu.lt; ${ }^{4}$ greta.kakneviciute@stud.vgtu.lt
}

\begin{abstract}
Inventory management and the related problems in manufacturing companies will always be a topical issue. In light of the fact that the manufacturing process must be continuous, there is an emerging need to build up inventories or to solve the issue of assurance of sufficient inventories by other means. Choosing an appropriate inventory management strategy is important in pursuit of this goal. This article examines peculiarities of inventory management strategies employed by Lithuanian manufacturing companies. The purpose is to investigate, what kind of strategies and for what reasons companies are using. This purpose was achieved during the conducted study based on the application of sophisticated questionnaire. Conducted research revealed that the applicability of JIT and 3PL inventory management strategies in Lithuania is limited.
\end{abstract}

Keywords: manufacturing companies, just in time (JIT), 3PL, inventories, inventory management strategies.

JEL Classification: D02, L60, O14.

\section{Introduction}

Inventory management and the related problems in manufacturing companies will always be a topical issue, because companies invest a significant share of their capital in building up inventories. Correct inventory management affects the time of order execution of manufacturing companies and their cash flows. In order to avoid downtime, specialists of the supply department usually purchase more inventories than necessary, thus freezing funds of the company. Such decisions affect the shortage in working capital, which may also disrupt the schedules of supply of raw materials being unable to pay suppliers of raw materials on time. The said problem may also lead to disruptions in the entire manufacturing process and dissatisfaction of customers when they do not receive the desired produce on time. In order to function properly and meet customer needs, manufacturing companies must manage their inventory responsibly. The management must include not only a decision on the optimal inventory levels, performance of technical and organizational storage operations, but also focus on funds invested in inventory in order to avoid losses.
The aim of the Article is to reveal inventory management strategies applied by manufacturing companies in Lithuania. The article starts with the theoretical analysis of importance of inventory management and problems that poor management of company's assets may lead to. Then introduction of JIT and 3PL inventory management strategies, and pros and cons of their application in manufacturing companies is discussed. Finally, results of empirical research of inventory management strategies applied by manufacturing companies in Lithuania are presented, and identification of inventory management strategies related problems are discussed. Article ends with summarizing conclusions.

\section{Peculiarities of inventory management in manufacturing companies}

In the broadest sense, manufacturing is an activity aimed at the creation of goods and services (Turovets, Rodionov, \& Bukhalkov, 2007). The modern approach to manufacturing is not limited to manufacturing a tangible product alone. Alijevas, Treigys, and Marcinkevičius (2012) de- 
scribes manufacturing as a process where economic resources of the society are targeted at the creation of a benefit in a tangible and ideal form. Depending on their intended purpose, manufacturing processes are divided into three types basic, auxiliary and servicing processes. Despite the nature of the manufacturing process, each manufacturing process comprises work, working instruments and object of work (Alijevas et al., 2012).

Since the manufacturing process must be continuous, there is an emerging need to build up inventories, which, according to Liaučius and Vaisiauskienè (2005), allow resolving consequences of disrupted manufacturing in manufacturing companies and ensuring a smooth process of the supply of customers with the necessary produce. According to M. Sharovatov, V. Sharovatov, and Kuznetsov (2000), inventories are large investments, which often play a very important role in the logistics system. Often inventories account for a half and more of current assets of companies (Christopher, 2005, 2007). Inventories are tangible values stored in the company, which the company uses to generate earnings within one year or in one business cycle. According to Murphy and Wood (2004), inventories are resources of goods and materials (raw materials) designated for different purposes, usually for meeting customer needs. Meanwhile, Garalis (2003a, 2003b) describes inventories as a part of company's assets and divides them into three groups: stored raw materials, work in progress and finished goods. Palšaitis (2003, 2010) states that inventories are one of factors allowing companies to stay profitable. To achieve this goal, company managers have to accurately decide on the time, quantities and frequency of ordering of inventories to meet customer needs and to minimize the total inventory management costs. Thus it is very important for companies to have an inventory management strategy.

In terms of organizational levels, an inventory management strategy is a functional level strategy, which means that it cannot function separately, i.e. an inventory management strategy must be integrated in the overall strategy of the entire organization (Mintzberg, 2015). An integrated approach to processes that take place in manufacturing companies and an ongoing analysis thereof leads to a much better matching of demand and supply, more accurate forecasts of inventory amounts and decreased inventory management costs. An integrated approach means that each process existing in the company is understood as a system, because such management allows improving the efficiency and effectiveness of organization's activities in pursuit of the goals set in the strategy. If a manufacturing company seeks for successful inventory management at the functional level, each inventory management-related process must identify weak spots, which cause the existing problems.

McCallion and Warner (2009) say that an ongoing review of the scope of inventories and an appropriate accounting system are very important inventory management factors. The majority of companies claim not to be losing sales, but the practice has shown that sales losses for a shortage of goods in warehouses account for an average of 10-20 percent of all sales of the company (Repečka, 2012). The following typical inventory management problems have been distinguished (Inventory Management, 2015):

- excessive loss of sales, shortage of certain goods in regional warehouses with excessive amounts of other goods;

- too many unplanned urgent shipments between warehouses;

- excessive returns of goods;

- insufficient capacities of manufacturers to fulfil all the submitted orders;

- shipment of excessive number of incomplete orders.

\section{Peculiarities of application of JIT and 3PL inventory management strategies in manufacturing companies}

Manufacturing companies must define and maintain an appropriate inventory management strategy, which would ensure adequate inventory levels for manufacturing and sale of goods, reducing the costs incurred (Sari, 2015). Control of inventory amounts is an important aspect directly related to the management strategy, because usually manufacturers seek to manufacture an amount of goods, which could be sold right away, at the same time keeping a respective inventory amount (Kokemuller 2015a, 2015b).

Manufacturing companies usually apply several inventory management strategies. In additional to the traditional one, JIT and/or 3 PL-based strategies can be distinguished.

The JIT-based inventory management strategy is an efficient tool for reducing expenses.

Table 1 presents the main differences between the JIT system and the traditional approach to inventories.

There are many examples of application of JIT in the world, for example, the apparel company "Zara", US companies "Limited" and "Gap" 
or the European retailers "Mango", "Mexx" and "Benetton". All of them are quick response logistics representatives using JIT-based inventory management strategies.

Table 1. Comparison of traditional and JIT inventory management strategies (Source: Žoramskè, 2009)

\begin{tabular}{|c|c|c|}
\hline Feature & $\begin{array}{c}\text { Traditional } \\
\text { strategy }\end{array}$ & $\begin{array}{c}\text { JIT } \\
\text { strategy }\end{array}$ \\
\hline $\begin{array}{l}\text { Quality } \\
\text { level }\end{array}$ & $\begin{array}{l}\text { Satisfactory qual- } \\
\text { ity at the lowest } \\
\text { cost }\end{array}$ & $\begin{array}{l}\text { Top quality - } \\
0 \text { defects }\end{array}$ \\
\hline $\begin{array}{l}\text { Inventory } \\
\text { amounts }\end{array}$ & $\begin{array}{l}\text { Large inventories } \\
\text { due to amounts } \\
\text { purchased at a dis- } \\
\text { count, manufactur- } \\
\text { ing volumes and } \\
\text { storage of reserve } \\
\text { inventories }\end{array}$ & $\begin{array}{l}\text { Low invento- } \\
\text { ries in pres- } \\
\text { ence of ongo- } \\
\text { ing JIT } \\
\text { deliveries }\end{array}$ \\
\hline Flexibility & $\begin{array}{l}\text { Long delivery } \\
\text { time, minimal } \\
\text { flexibility }\end{array}$ & $\begin{array}{l}\text { Minimal de- } \\
\text { livery time, } \\
\text { high flexibil- } \\
\text { ity }\end{array}$ \\
\hline $\begin{array}{l}\text { Transporta- } \\
\text { tion }\end{array}$ & $\begin{array}{l}\text { Satisfactory ser- } \\
\text { vice level at the } \\
\text { lowest cost }\end{array}$ & $\begin{array}{l}\text { Absolutely re- } \\
\text { liable service } \\
\text { level }\end{array}$ \\
\hline $\begin{array}{l}\text { Seller-car- } \\
\text { rier rela- } \\
\text { tions }\end{array}$ & $\begin{array}{l}\text { Frequent disagree- } \\
\text { ments }\end{array}$ & Joint venture \\
\hline $\begin{array}{l}\text { Number of } \\
\text { suppliers/ } \\
\text { carriers }\end{array}$ & $\begin{array}{l}\text { Large; reduction is } \\
\text { not a way out }\end{array}$ & $\begin{array}{l}\text { Low; continu- } \\
\text { ous coopera- } \\
\text { tion }\end{array}$ \\
\hline $\begin{array}{l}\text { Seller-car- } \\
\text { rier rela- } \\
\text { tions }\end{array}$ & $\begin{array}{l}\text { Minimum; many } \\
\text { secrets; strict con- } \\
\text { trol }\end{array}$ & $\begin{array}{l}\text { Open; ongo- } \\
\text { ing exchange } \\
\text { of information } \\
\text { and coopera- } \\
\text { tion }\end{array}$ \\
\hline $\begin{array}{l}\text { Main pur- } \\
\text { pose of ac- } \\
\text { tivities }\end{array}$ & $\begin{array}{l}\text { Activities are } \\
\text { based on cost } \\
\text { management }\end{array}$ & $\begin{array}{l}\text { Activities are } \\
\text { aimed at man- } \\
\text { aging cus- } \\
\text { tomer service }\end{array}$ \\
\hline
\end{tabular}

However, despite the benefits of the JITbased inventory management strategy, there also are certain deficiencies that cause problems for manufacturing companies seeking to adopt this system (Darm, 2013):

- JIT system has no tolerance for mistakes, which is very difficult to implement in practice;

- manufacturing companies must rely on suppliers of raw materials;

- disruptions in the supply of raw materials lead to disturbances in the manufacturing process.
Fullerton and McWatters (2001) distinguish a few more drawbacks of the JIT system:

- Complex and expensive implementation;

- Continuity of the manufacturing process not guaranteed;

- Increasing costs of administration and transportation of goods;

- Companies are not always able to find suppliers which would meet strict JIT requirements.

Having revealed pros and cons of the JIT system, cases when the implementation of the JITbased inventory management strategy is expedient can be distinguished:

- manufacturing companies incur significant storage expenses;

- inventories age quickly;

- nomenclature of inventories is minor;

- suppliers are close to manufacturing sites;

- companies do not need large amounts of reserve inventories.

According to Peterson (2007), "JIT is not an inevitable evil and must be carefully analysed, or it can become a real nightmare." Manufacturing companies should carefully and responsibly assess their needs, opportunities and market developments, and deliberately decide on choosing a JITbased inventory management strategy.

Taking the advantage of a Third Party Logistics (3PL)-based inventory management strategy is beneficial for manufacturing companies seeking to implement efficient inventory management strategies. The following pros of 3PL can be distinguished:

- reduced costs;

- high customer service level;

- reduced inventory expenses;

- focusing resources on core activity;

- flexible supply technologies.

On the other hand some cons also should be mentioned:

- dismissal of employees;

- decreasing control;

- lack of information (Miškauskaite, 2009).

Having assessed pros and costs of 3PL, manufacturing companies must distinguish the criteria forming the basis for their decision on the application of the inventory management strategy based on this system. The setting of the criteria is necessary in order to correctly and expediently choose partners for the implementation of this strategy. Alfredson and Hertz (2003) say that one of the main criteria of a manufacturing company - 
a client - is the benefit, which it expects to receive ordering 3PL services, and this depends on the ability of the company - the service provider - to distribute the available resources to its customers and the level of integration in the activities of its customers.

The conducted analysis of scientific sources revealed that inventories cannot be avoided in manufacturing companies, because they balance the supply and demand, and prevent from surprises. The importance of inventory management allows treating inventory management solutions as an inventory management strategy, which must be chosen having assessed the current situation, the benefit of 3PL or JIT inventory management and integration in the general strategy of the organization.

\section{Investigation of inventory management strategies in manufacturing companies in Lithuania}

In the preparation of an empirical research of peculiarities of inventory management strategies in manufacturing companies in Lithuania, two main goals were set:

a) to find out if manufacturing companies use inventory management strategies;

b) to find out the benefits of application of Third-party logistics (3PL) and Just-intime (JIT) principles-based inventory management strategies in these companies.
The object of the research was inventory management strategies of manufacturing companies of various sizes located in Lithuania.

A questionnaire method was chosen for carrying out the research. Questionnaires were sent to 224 companies producing various goods. The number of respondents was calculated through the Paniotto formula and was supposed as the sufficient to assure validity of research. However, just 59 respondents answered the questions, with feedback being 26.34 percent. Therefore results of the study could not be treated as representing the real situation in Lithuania, but rather pointing out general trends.

First of all, the aim was to find out the type of goods which respondent companies produce. Based on the received results, companies were distinguished to respective categories provided below (see Figure 1).

Activities of manufacturing companies are usually not limited to the manufacturing of goods alone. The received results allow stating that usually manufacturing companies are additionally engaged in:

- warehousing of goods, with 33.90 percent of companies which took part in the survey being engaged in it,

- organization of transportation activities - 20.34 percent of companies,

- planning of distribution of goods -16.10 percent,

- packaging of goods - 15.25 percent;

- consolidation of manufactured goods 6.78 percent.

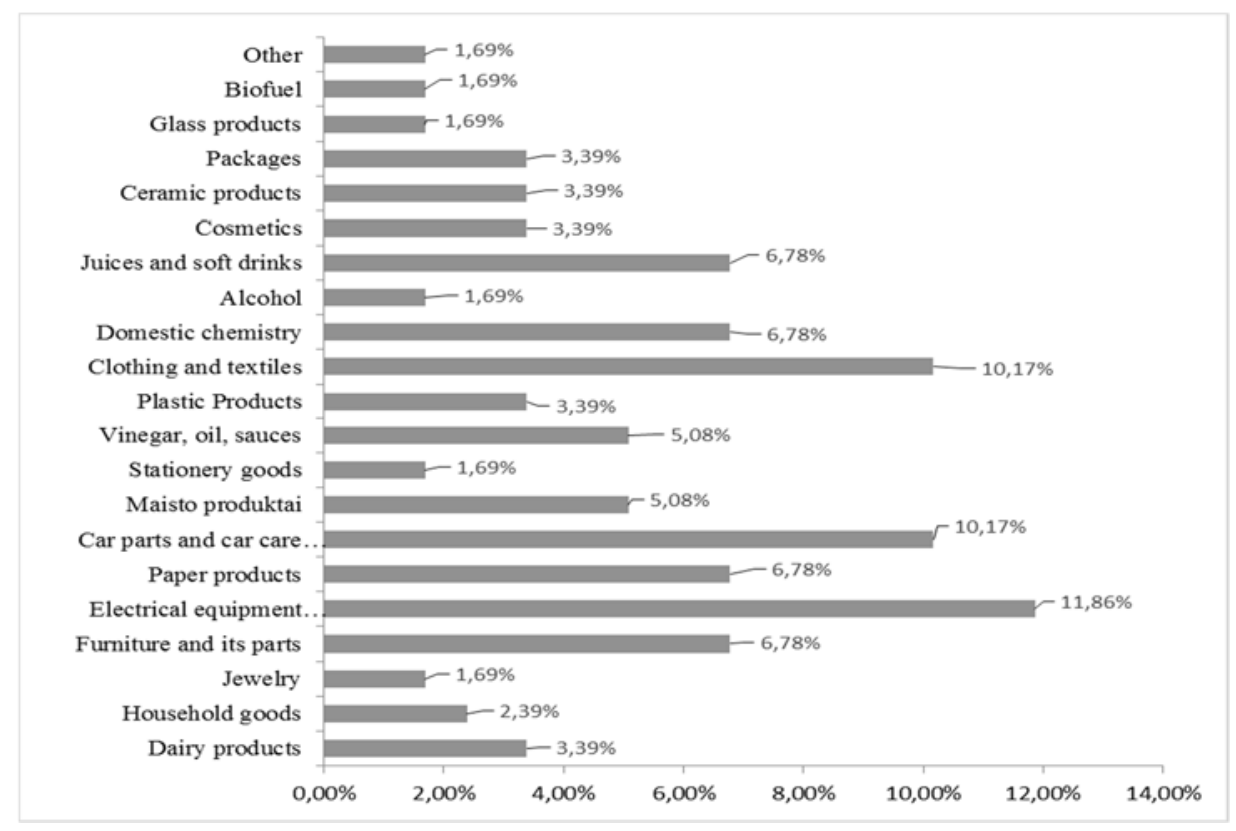

Figure 1. Distribution of companies by manufactured goods (compiled by the authors) 
The rest (or 7.63 percent) of companies chosen the answer "other", i.e., named several additional activities, with the organization and promotion of sales and website administration being mentioned most frequently. It is obvious that not a single surveyed company was focused on its core activity - manufacturing - alone; all of them have been organizing additional activities, allocating additional human, time, financial and other resources therefor.

During the research, 86.44 percent of respondents were found to be building up inventories. The results allow stating that manufacturing companies do not manage to organize their activities without building up inventories. The following are the identified reasons for building up inventories in manufacturing companies in Lithuania:

- required long product fermentation, uneven demand;

- concluded contracts with customers on the warehousing of goods;

- aim to be ready to meet the demand occurred at any time;

- inventories necessary for constant supply to sales points;

- inventories ensure continuous manufacturing;

- manufacturing is ongoing, thus inventories build up automatically;

- protection from possible shortage of goods;

- lower cost of transportation when carrying larger amounts;

- instability of product orders;

- export of goods encourages the build-up of inventories.

Respondents named the priority aim of activities to ensure continuous manufacturing and supply of goods to sales points or directly to customers as the main reason for building up inventories. In such a case, inventories protect from potential shortage of goods and allow meeting customer needs at any time. Building up inventories for manufacturing companies can be stated to be inseparable from the conducted activities in order to regulate supply and demand.

The conducted research also revealed how the inventory management strategy is understood in manufacturing companies in Lithuania. Respondents stated that the inventory management strategy is:

- an instrument for storing goods at the lowest cost;
- monitoring of the movement of goods from the moment of their manufacture till they get to a warehouse;

- management of the supply and manufacturing cycle;

- a method allowing maintaining the set inventory amounts;

- a system, which helps manage inventories;

- inventory accounting methodology;

- a method to avoid financial costs in determining the need for building up inventories;

- a documented strategy for inventory control;

- a plan for building up inventories;

- supply with inventories when the optimal level thereof is maintained;

- purposeful and well thought-out monitoring of inventory amounts;

- maintaining such inventory amounts, which would be neither excessive nor too low.

In summary, Lithuanian manufacturers can be said to associate this concept with the setting and maintenance of the optimal inventory amount based on accurate calculations, reduction of expenses related to inventory management, increase of return on the company's investment in inventories and performance efficiency. Even though the majority of respondents quite accurately defined the inventory management strategy and its intended purpose, when asked if companies apply the said strategy, 52.54 percent said that they do not use the strategy, while 45.75 percent answered that they do apply it and 1.69 percent of respondents did not answer this question altogether.

Respondents, who said that they use inventory management strategies, were asked to provide reasons for using them:

- the pursuit to distribute the manufactured goods at the lowest cost;

- the aim to monitor the movement of goods, increasing the efficiency of search in the warehouse;

- allows avoiding a shortage of goods;

- offered wide assortment of the manufactured goods, thus there must be sufficient quantities of raw materials for manufacturing;

- identification of risks;

- inventory control;

- helps reduce inventory management-related costs; 
- saves funds, without freezing cash; allows working more conveniently;

- helps reduce cost and ensure continuity of the manufacturing process;

- required by management;

- helps efficiently use the warehouse area, without any surplus;

- there is a developed quality management policy, and an inventory management strategy is one of the aspects thereof.

The application of an inventory management strategy is an important decision for manufacturing companies, because it allows controlling inventory amounts thus efficiently exploiting warehousing areas and reducing costs of inventory management; companies are able to invest more in the manufacturing process itself and its improvement, which should be the main goal of manufacturers.

The research revealed that as many as 50.85 percent of manufacturing companies have transferred respective activities, such as the carriage of goods, warehousing, etc., to an external company - a 3PL service provider.

Having examined the relevance of $3 \mathrm{PL}$ to manufacturing companies, a JIT-based inventory management strategy and its applicability were analysed in the second part of the research. The majority of companies applying a JIT-based inventory management strategy mainly emphasized high quality of the manufactured goods -20.34 percent. 16.95 percent of respondents noted that minimum amounts of manufacturing rejects and waste are typical of the inventory management strategy of companies; 13.56 percent of respondents said that attempts are made to maintain small inventory amounts. 11.86 percent of companies having taken part in the survey have automated manufacturing, while 10.17 percent of respondents cooperate with a few suppliers and carriers only, which most likely determines minimal shipping costs and time. 8.47 percent of respondents also noted that their companies focus on customer service, because a satisfied customer is a loyal customer. The received results reveal that inventory management strategies of the surveyed companies are relatively close to the JIT manufacturing organization system or have at least one of the characteristics of the said system.

The barriers, which prevent manufacturing companies from using 3PL and JIT-based inventory management strategies, were analysed in the course of the research. Table 2 presents summarized results.

74.58 percent of respondents consider 3PLbased inventory management strategy to be more acceptable. 18.64 percent marked JIT-based strategy as more acceptable and 6.78 percent did not answer this question altogether.

Table 2. Potential barriers in application of 3PL and JIT-based inventory management strategies identified by manufacturing companies (compiled by the authors)

\begin{tabular}{|c|c|}
\hline $\begin{array}{c}\text { Barriers in application of 3PL-based inventory } \\
\text { management strategies }\end{array}$ & $\begin{array}{c}\text { Barriers in application of JIT-based inventory } \\
\text { management strategies }\end{array}$ \\
\hline $\begin{array}{l}\text { Opinion that conducting all activities on one's own is } \\
\text { cheaper is still very viable; } \\
\text { Predicting if goods will be manufactured in a timely } \\
\text { manner is difficult; } \\
\text { Controlling external activities of the company is diffi- } \\
\text { cult; } \\
\text { Distrust in suppliers and carriers; } \\
\text { Other companies are not trusted, thus various hardly } \\
\text { implementable requirements are raised; } \\
\text { A fear that services will deceive or disappoint; } \\
\text { Companies do a lot of work themselves, thus transfer- } \\
\text { ring one function to another company is inexpedient; } \\
\text { Services of potentially poor quality; } \\
\text { Limited control; } \\
\text { Complex coordination of mutual interests; } \\
\text { A large number of carriers, high prices; } \\
\text { Information on experience of other companies is insuf- } \\
\text { ficient. }\end{array}$ & $\begin{array}{l}\text { Forecasting needs in the long term is hard; } \\
\text { Keeping small amounts of inventories only and } \\
\text { continuously monitoring changes therein is diffi- } \\
\text { cult; } \\
\text { Difficult adaptation process from both technologic } \\
\text { and financial perspective; } \\
\text { Expensive implementation; } \\
\text { High costs because of expensive automatization of } \\
\text { manufacturing; } \\
\text { Employees will have to be trained; some of them } \\
\text { may have to be dismissed; } \\
\text { Inapplicable in small companies; } \\
\text { Requires major reforms in the company; } \\
\text { Time consuming process; } \\
\text { Cannot be applied in all cases; } \\
\text { Risk to run short of raw materials; } \\
\text { Instability of orders. }\end{array}$ \\
\hline
\end{tabular}


The survey revealed that the majority of companies build up inventories in leased warehouses without applying an inventory management strategy, even though when defining its concept, they also identified the benefits thereof. Companies, which apply an inventory management strategy, noted that their strategies have respective 3PL and JIT manufacturing system organization features, but they identified 3PL-based inventory management strategy as a more acceptable option, because respondents believed the implementation of JIT to be time consuming, very expensive and requiring reorganization of the manufacturing process, meanwhile 3PL was based on the principle that a manufacturing company transfers some of its conducted activities to companies providing $3 \mathrm{PL}$ services.

\section{Conclusions}

The application of an inventory management strategy in manufacturing companies is of vital importance, and has a direct impact on the financial results of given company. Inventory management strategy based on the "Just-in-time" (JIT) concept is an effective cost-cutting tool while "Third-party logistics" (3PL) principles - based inventory management strategy allows manufacturing companies to focus on their core activity manufacturing - and thus affects level of cost and level of service of particular company.

Investigation of Lithuanian manufacturing companies' revealed that $86.44 \%$ of companies build up inventories in order to assure uninterruptable manufacturing and supply of goods to sales points or directly to customers. Also respondents declared that inventories prevent from possible shortage of goods in the future and allow meeting customer needs at any time.

Manufacturers associate the inventory management strategy concept with the setting and maintenance of the optimal inventory amounts based on accurate calculations, the reduction of inventory management - related expenses, company's return on investment in inventories and increasing performance efficiency. However, the majority of respondents do not apply any inventory management strategy.

Conducted research revealed that the applicability of inventory management strategies based on JIT and 3PL principles in manufacturing companies in Lithuania is limited due to number of reasons, the most important being the need for reorganization of activities, expensive implementation and lack of information.
The main findings of the conducted research correlate with theoretical postulates about pros and cons of different inventory management strategies and the fact that such strategies sometimes can be very difficult to adapt and implement. On the other hand, revealed situation lays firm background for the future investigations of inventory management peculiarities in Lithuanian manufacturing companies, and this article should be treated just as the first step in this direction.

\section{References}

Alijevas, F. M., Treigys, P., \& Marcinkevičius, V. (2012). Gamybos proceso ir resursų planavimo sistemu struktūros analizè. Mokslo taikomųjų tyrimų ịtaka šiuolaikinių studijų kokybei. Iš 5-osios respublikinès mokslinés-praktinès konferencijos moksliniu straipsniu rinkinio (pp. 5-10). Vilnius: Vilniaus kolegijos Elektronikos ir informatikos fakultetas.

Alfredson, M., \& Hertz, S. (2003). Strategic development of third party logistics providers. Industrial Marketing Management, 32(2), 139-149. https://doi.org/10.1016/S0019-8501(02)00228-6

Inventory Management. (2015). Atsargu valdymas. Retrieved from http://www.toc.lt/lt/seminarai/atsarguvaldymas-tiekimo-grandines-valdymas

Christopher, M. (2005). Logistics and supply chain management. Creating value-adding networks. Great Britain: Prentice Hall.

Christopher, M. (2007). Logistika ir tiekimo grandinès valdymas. Vilnius: Eugrimas.

Darm, L. (2013). Just-in-time shipping makes manufacturing more efficient. Jacksonville Business Journal. Retrieved from http://www.bizjournals.com/jacksonville/print-edition/2013/02/08/just-in-time-shippingmakes.html?page $=$ all.

Fullerton, R., \& McWatters, C. S. (2001). The production performance benefits from JIT implementation. Journal of Operations Management, 19(1), 5-10. https://doi.org/10.1016/S0272-6963(00)00051-6

Garalis, A. (2003a). Logistika: bendrieji pagrindai. Šiauliai: Šiaulių universiteto leidykla.

Garalis, A. (2003b). Logistikos terminu aiškinamasis žodynas. Šiauliai: Šiaulių universiteto leidykla.

Kokemuller, N. (2015a). What is the difference between raw material inventory and finished goods? Retrieved from http://smallbusiness.chron.com/difference-betweenraw-material-inventory-finished-goods-70127.html.

Kokemuller, N. (2015b). What is production inventory?. Retrieved from http://smallbusiness.chron.com/production-inventory-17468.html.

Liaučius, N., \& Vaisiauskienè, R. (2005). Individualios imonès atsargu valdymo sistemos analizè. Retrieved from http://www.ebiblioteka.lt/resursai/Konferencijos/KTU_PI/KNYGA2005\%20PDF/straipsniai/Vadyb os/Vaisiauskiene,\%20Liaucius\%201.pdf

McCallion, R., \& Warner, A. (2009). Smulkaus verslo pinigu srautas. Vilnius: Conto Litera.

Mintzberg, H. (2015). Mintzberg's 5 Ps of Strategy. Retrieved from http://www.mindtools.com/pages/article/mintzberg-5ps.htm. 
Miškauskaitè, J. (2009). Trečiuju šaliu logistikos paslaugos Lietuvoje. Retrieved from http://vddb.library.lt/fedora/get/LT-eLABa-0001:E.02 2009 D_20140626 181822-31088/DS.005.0.01.ETD.

Murphy, P., \& Wood, D. (2004). Contemporary logistics. New Jersey: Pearson Education International.

Palšaitis, R. (2003). Logistikos pagrindai. Vilnius: Technika.

Palšaitis, R. (2010). Šiuolaikine logistika. Vilnius: Technika. https://doi.org/10.3846/1107-S

Peterson, T. (2007). Modeling customize product configuration in large assembly manufacturing with supplychain considerations. International Journal of Flexible Manufacturing Systems, 19(4), 685-712. https://doi.org/10.1007/s10696-008-9041-0

Repečka, E. (2012, gegužè). Atsargų valdymas: Atsargu saugojimo išlaidos, stebèsena ir analizè. Iš 15-osios Lietuvos jaunuju mokslininku konferencijos ,,Mokslas-
Lietuvos ateitis“ teminès konferencijos „Transporto inžinerija ir vadyba" straipsniu rinkinio (pp. 209-212). Vilnius: Technika.

Sari, J. (2015). Defining an inventory strategy. Retrieved from http://www.ur.mx/cursos/post/obarraga/base/ inv.htm.

Žoramskè, I. (2009). UAB „,Sander Baltic“ aprūpinimo sistemos tobulinimas. Master Thesis. Vytautus Magnus University.

Sharovatov, M., Sharovatov, V., \& Kuznetsov, M. (2000). Transportnaya logistika. Retrieved from http://www. logistika.spb.ru/logistics/transport.

Turovets, O. G., Rodionov, V. B., \& Bukhalkov, M. I. (2007). Proizvodstvennyy protsess i osnovnye printsipy ego organizatsiy. Retrieved from http://www.cfin.ru/ management/manufact/product_process.shtml. 